\title{
'n Vrou, 'n plaas en briewe uit die nag
}

\begin{tabular}{|c|c|}
\hline \multicolumn{2}{|c|}{$\begin{array}{l}\text { Book Title: } \\
\text { Briewe uit Brielshoop }\end{array}$} \\
\hline \multicolumn{2}{|l|}{ Book Cover: } \\
\hline \multicolumn{2}{|c|}{$\begin{array}{l}\text { BRIEWE UIT } \\
\text { BRIELSHOOP } \\
\end{array}$} \\
\hline \\
\hline \multicolumn{2}{|c|}{ Helene Olivier } \\
\hline \multicolumn{2}{|c|}{ se. } \\
\hline \multicolumn{2}{|l|}{ Author: } \\
\hline \multicolumn{2}{|c|}{ ISBN: } \\
\hline \multicolumn{2}{|c|}{ Publisher: } \\
\hline \multirow{2}{*}{\multicolumn{2}{|c|}{$\begin{array}{l}\text { Protea Boekhuis, 2018, } \\
\text { R210* } \\
\text { *Book price at time of review }\end{array}$}} \\
\hline & \\
\hline \multicolumn{2}{|c|}{$\begin{array}{l}\text { Review Title: } \\
\text { 'n Vrou, ' } n \text { plaas en briewe uit } \\
\text { die nag }\end{array}$} \\
\hline \multicolumn{2}{|c|}{ Reviewer: } \\
\hline $\begin{array}{l}\text { Affiliation: } \\
{ }^{1} \text { Faculty of Ed } \\
\text { Sciences, Nor } \\
\text { University, Po } \\
\text { South Africa }\end{array}$ & $\begin{array}{l}\text { ucation } \\
\text { ch-West } \\
\text { tchefstroom, }\end{array}$ \\
\hline \multicolumn{2}{|c|}{$\begin{array}{l}\text { Corresponding author: } \\
\text { Susan Meyer, } \\
\text { meyer.susan@nwu.ac.za }\end{array}$} \\
\hline \multicolumn{2}{|c|}{$\begin{array}{l}\text { Meyer, S., 2019, "n Vrou, } \\
\text { 'n plaas en briewe uit die } \\
\text { nag', Literator 40(1), a1621. } \\
\text { https://doi.org/10.4102/lit. } \\
\text { v40i1.1621 }\end{array}$} \\
\hline \multicolumn{2}{|c|}{$\begin{array}{l}\text { Licensee: AOSIS. This work } \\
\text { is licensed under the } \\
\text { Creative Commons } \\
\text { Attribution License. }\end{array}$} \\
\hline \multicolumn{2}{|l|}{ Read online: } \\
\hline 口ita & $\begin{array}{l}\text { Scan this QR } \\
\text { code with your } \\
\text { smart phone or } \\
\text { mobile device } \\
\text { to read online. }\end{array}$ \\
\hline
\end{tabular}

'Beeste is makliker as mense. Maar wanneer ek Bonsma en John Evelyn in die nanag lees, wonder ek of ek enigiets van beeste verstaan of van bome.' Só skryf Henna, onervare boer en denkende, filosofiese siel, aan haar vriendin Ida, 'n joernalis in die stad.

Terwyl Henna en haar man juis op soek is na 'n stukkie grond waar hulle saam kan ontspan, weg van die kwellings van die stadslewe, erf sy onverwags 'n familieplaas. Pleks van die plaasidille wat Stone, haar man en toegewyde medikus, voorgehou het, word Henna gekonfronteer met die harde werklikheid van 'n volskaalse boerdery. Terwyl Stone se pligte hom in die stad besig hou, is dit Henna wat vendusies bywoon, kalwers versorg, met plaasarbeiders onderhandel en 'n tuiste uit 'n murasie probeer skep. Vrou-alleen kom sy tot insig oor die intense aard van boerdery, wat sy met toenemende moedeloosheid maar ook met reddende humor opsom as 'n:

... gesukkel met die bank, die koöperasie, met werkers en gebrek aan werkers, met buurmanne en -vroue, [...] met rade, onrade en ander ongediertes en die beheerliggame oor die ongediertes, siektes, markte, tekort aan markte, produksiepryse en afwesigheid van produksiepryse, tekorte, oorskotte, droogtes, agente en spekulante. (bl. 50)

In hierdie briefroman ontvou egter ook die verhaal van 'n ouerwordende vrou wat stoei met haar komplekse familiegeskiedenis en onopgeloste geheime ná haar ma se dood. My waardering vir die roman is gegrond op twee uitstaande aspekte. Eerstens is ek verras deur die behendigheid van styl waarmee Henna haar plaasbelewings neerpen en haar terselfdertyd as baie interessante vrou openbaar: belese, fyngevoelig en intellektueel, en met die hart van 'n bewaringsgeoriënteerde boer. Tweedens, is daar die vaardige ontwikkeling van 'n verhaal uit die briewe en die bevredigende ervaring om dit self te konstrueer uit die los dele, uit die verskeidenheid van beskrywings en vertellings en vertwyfelings waarin daar brokke van Henna se lewe vasgevang word.

Soos Heilna du Plooy (2019) die leser in haar resensie oor die boek herinner, is die bepalende eienskap van briefliteratuur die dominante stem en gesigspunt van die skrywersinstansie. Hierin lê die outensiteit van 'n brief opgesluit. Die sterk outentieke kleur van Henna se briewe lê in die treffende eerlikheid, die vlymskerp spot met haar eie swakhede, maar ook die pynlik akkurate waarneming van die wêreld en verhoudings waaroor sy skryf.

Ten spyte van die vertroulike aard van die briewe aan haar vriendin, is die styl nie kletserig nie. Die stukke is klein essays; subjektiewe sowel as kritiese beskouings van die boerderysituasie, maar ook van die sosiale en politieke omgewing waarin sy leef. Henna skryf met skerp opmerksaamheid oor die lewens rondom haar - dié van die werksmense op die plaas én die mense op haar dorp - binne die groter konteks van die land in die jare 1977 tot 1994. Die essayistiese styl en denkende inslag in die briewe vloei saam met deurlopende verwysings na die letterkunde ten einde die gang van haar denke te illustreer.

Ten opsigte van die agterliggende verhaal wat die leser uit die briewe rekonstrueer, is daar deurlopende en tydloos aktuele motiewe. Komplekse verhoudings is die mees opvallende daarvan, en die ondersoekende en kritiese blik op die self bied telkens 'n nugter perspektief op die saak. Vingeralleen op die plaas wat haar en Stone se gesamentlike droom was en gedeelde projek moes gewees het, bespiegel Henna oor die situasie van die verhoudingsmaat wat 'weer weg, altyd weg' is wanneer sy hom werklik nodig het (bl. 226). Die 'langarmboerdery' word ook 'n 'langarmhuwelik' (bl. 187); Henna dwing haar egter ook, op kenmerkend selfondermynende wyse, om te erken dat dit Stone se kwaliteite eerder as haar eie kapasiteit is wat keer dat sy 'gillend uit die huwelik weghol' (bl. 202).

Haar verhouding met haar skoonpa kom opnuut en pynlik onder die soeklig wanneer hy sterf; hy was die 'Christen gentleman' na wie se hart sy nooit 'n pad kon vind nie, maar oor wie sy toegee dat sy soveel méér moeite kon gedoen het. Haar skuldgevoel oor haar ma setel in die wete dat dit die 'preutse ou dogter' in haar was wat nooit die ouer vrou se ekstroverte en uitdagende lewenstyl 
wou aanvaar nie (bl. 205). Menslike drama en menslike feilbaarheid is kernbestanddele wat die verhaalgegewens bymekaar hou.

Die aangrypende van die verhaallyn lê vir my in die momente wanneer die mens sy beperkings oorstyg, soos wanneer Henna op universele vlak 'n soort verbintenis van empatie met die ooi smee wat sukkel om 'n band met haar pasgebore tweeling te vorm, en die dier dan deur haar vrees probeer práát, desperaat grypend na enige denkbare onderwerp, selfs die letterkunde en biologie (bl. 206). Of wanneer sy saam met die gemeenskap verslae deur die oorweldigende droogte, poog om 'iets lewends uit die droogte te dwing' en "n skerf van die ewigheid' in 'n bottel helder konfyt vas te vang (bl. 203).

Briewe uit Brielshoop bied 'n onpretensieuse en eerlike blik op die 'onwennigheid' van menswees, die 'onhandigheid' en 'onkapabelheid', maar ook die verkwiklike daarvan (bl. 196, 197). Die briewe word waardige roman. Dit sal vir lesers wat menslike diepte in romankarakters waardeer, 'n baie positiewe leeservaring wees.

\section{Literatuurverwysings}

Du Plooy, Heilna, 2019, Briewe uit Brielshoop deur Helene Olivier: 'n Resensie, LitNet, geraadpleeg 01 Mei 2019, vanaf https://www.litnet.co.za/briewe-uit-brielshoopdeur-helene-olivier-n-resensie/. 